\title{
Parking Demand Forecasting in Airport Ground Transportation System: Case Study in Hongqiao Airport
}

\author{
Lin Chang $^{1, \text { a }}$, Li Weifeng ${ }^{1, b^{*}}$, Huanh Yan ${ }^{2, c}$, Yang Ge $\mathrm{e}^{1, \mathrm{~d}}$ \\ ${ }^{1} 4800$ Cao'an Road, Jiading District, Shanghai, China \\ ${ }^{2} 901$ North Zhongshan Road(2nd), Yangpu District, Shanghai, China \\ ${ }^{a}$ Linch@tongji.edu.cn, ${ }^{b}$ lwf0103@gmail.com, ${ }^{c}$ yanggeli@163.com, ${ }^{d}$ smedi \\ _hq@163.com
}

\begin{abstract}
This paper addressed the parking demand forecasting in airport ground transportation system, and demonstrated here in Hongqiao Airport. The moving-average model (MA model) is used to model and estimate the parking demand with the scheduled arrival passengers and the departure passengers. The results indicated that all the coefficients are significant which confirmed the validation of the proposed approach.

Keywords: Hongqiao Airport; Ground transportation; Parking demand forecasting; ARIMA model

\section{Introduction}

Hongqiao International Airport is situated in the western outskirts of Shanghai, China, about 13 kilometers (about 8 miles) from downtown area and about 60 kilometers (about 37 miles) from Pudong International Airport. Being the first civilian airport in Shanghai, Hongqiao International Airport is more than eighty years old. After a series of renovations, it has become one of the three international air transit centers in China. 91 airlines currently fly from here to both domestic and international cities.
\end{abstract}


Hongqiao Airport Terminal 2 is built-up and come into usage on March 16, 2010, which is a support to 2010 Shanghai Expo. After the extension, it shown to the public a new terminal with a new runway of 3300 meters and a new set of assistant facilities, especially a high-efficient airport ground transportation system. The new airport ground transportation system includes two metro lines, several bus lines and airport express, and taxis system, and also parking-lot for passengers who arrived by private cars.

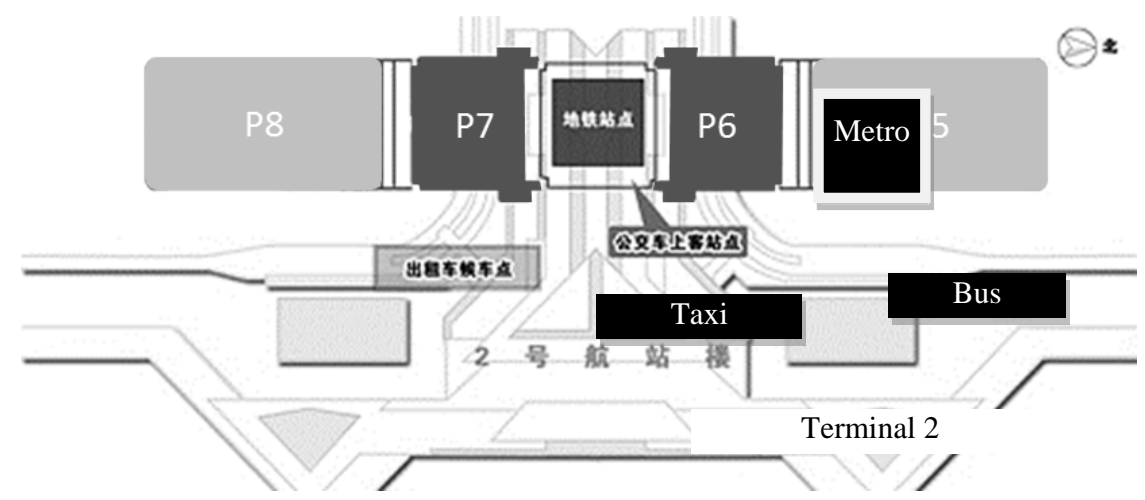

Fig. 1 Illustration of the parking lots in Terminal 2

However, with the rapid development of motorization in China, more and more people have shifted to rely on private cars as their primary travel modes. It not only caused the severe congestion on urban road network and more gas emission, but also lead to the lack of sufficient parking-lots, especially in central business districts (CBD) or external transport hubs such as Hongqiao Airport and Pudong Airport. Taking Hongqiao Airport Terminal 2 as an example, there are 4 parking lots now in service for Terminal 2. The parking lots are located on the two sides of the eastern part of the transportation center, which is connected with the terminal, shown in Fig. 1.

P6 and P7 parking lots are for light-duty vehicles only (only cars lower than 1.9 meters are allowed in), while P5 and P8 parking lots are for oversized vehicles. Here we refer to the private-car parking lots (P6 and P7) which are with a total of 3,140 parking spaces available. Nevertheless, after the 4 years' development, the problem of insufficient parking spaces during the peak-hours of flights has been 
more and more severe in Terminal 2. As shown in Fig. 2, the average parking saturability especially in P7 has nearly reached the 1.0, while the worst-case parking saturability during peak hours in both parking lots have been over-saturation. A new round of parking lots planning and construction should get started and new operation management measures should be deployed.

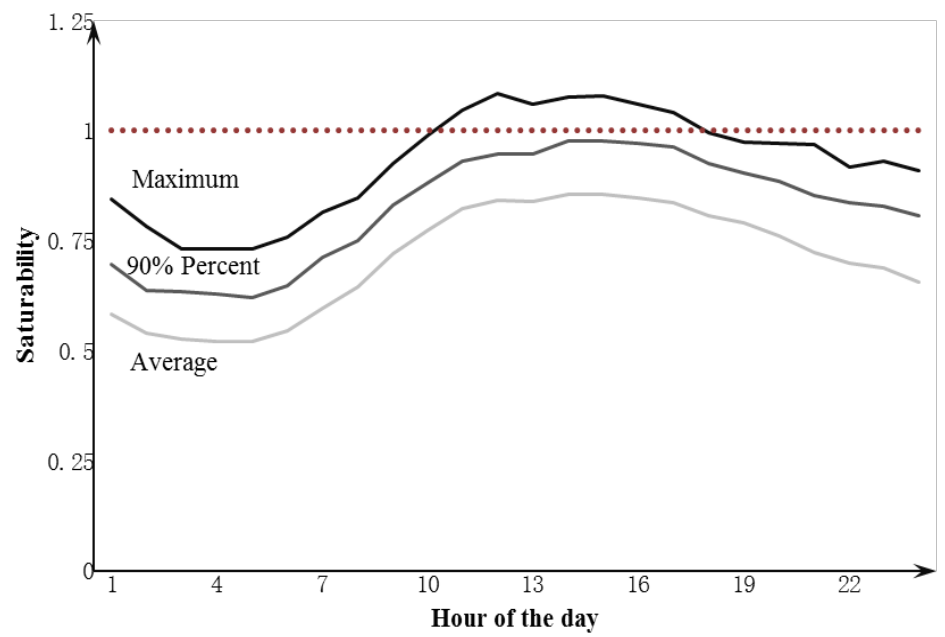

Fig. 2(a) Illustration of parking saturability changes according to hour of day in P6

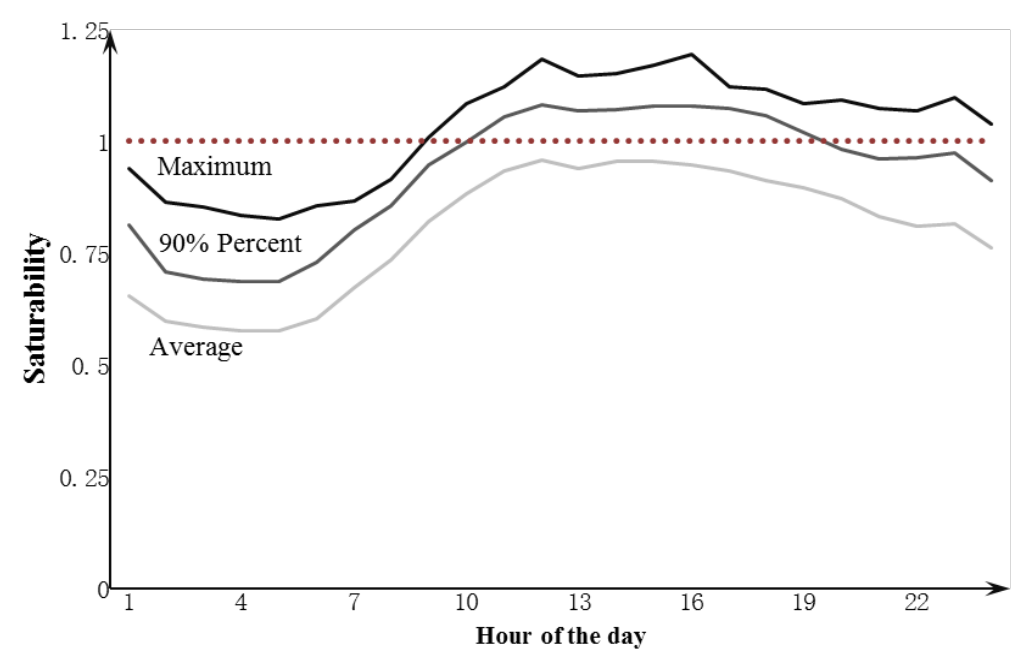

Fig. 2(b) Illustration of parking saturability changes according to hour of day in P7 
Thus, in terms of the next-step airport parking lots planning and efficient comprehensive airport ground transportation system manegement, this paper addressed the parking demand forecasting of the parking lots in Hongqiao Airport, based on the available data of parking occupancy and the numbers of flight passengers.

\section{Literature Review}

In the recent decades, a number of works have been focusing on the area of parking demand forecasting. A SPGR model based on land use and LC Model based on private car trips were established in [1]; Chen established another SPGR Model and then gave a precise algorithm to analyze the influence factors of parking demand [2]; Guan established a PSDF Model [3]. According to construction indices from the planned land in all traffic areas, Zhang set up an improved SPGR Model to forecast parking demand [4]. Under the limitation of network capacity and network service level, Bai, et al modified an OD forecast and parking demand forecast method [5].

\section{Model of Parking Demand Forecasting}

Model Construction. The moving-average model (MA model) is used to model the univariate time series models in the time series analysis. With the scheduled arrival passengers $A_{i}$ and the departure passengers $D_{i}$ of the $i$-th time period as input, the parking demand $X_{i}$ can be estimated based on the MA model. The notation of the proposed model is written

$$
X_{t}=\mu+\varepsilon_{t}+\sum_{i=1}^{q} X_{t} \varepsilon_{t-i}+\sum_{i=1}^{m} A_{t+i} \theta_{i}+\sum_{i=1}^{n} D_{t+i} \phi_{i} .
$$


where $\theta_{i}, \phi_{i}$ are the parameter of the model, $\mu$ is the expectations of $X_{t}$, and $\varepsilon_{t}, \varepsilon_{t-1}, \cdots, \varepsilon_{t-q}$ are the white noise error terms. The moving-average model is essentially a finite impulse response filter with some additional interpretation placed on it. The proposed algorithm in this paper is capable of the parking demand estimation and adaptation to suit the changing situation of passenger arrivals, passenger departure, flight delays and parking demand in prior periods. The output can be applied as the reference of early-warning and the relevant countermeasures.

Parameter Determination. The parameters in the Equation (1) are determined based on the basic assumptions listed as follows.

1 According to the statistical results of the parking time in Hongqiao Airport, the vehicles whose parking time is more than three hours represents just twelve percent of all the parking vehicles. The assumption is made that the current occupancy of parking space is influenced by the occupancy of the past two hours. Therefore, the parameter $q$ is determined to be 2 .

2 The occupancy of parking spaces is influenced by the departure passengers. Hongqiao Airport is the main domestic airport serving Shanghai. For the passengers of domestic flights, the recommended arrival time at the airport prior to the departure of flights is usually two hours. Thus, the parameter $n$ is determined to be 3 .

3 The occupancy of parking spaces is also influenced by the arrival passengers. Taking the results of passenger trace observation in Hongqiao Airport and the delay of flights into consideration, the parameter $m$ is determined to be 2.

Results and Discussion. The parking lots of Hongqiao Airport are divided into two separated parts: the northern part and the southern part. The parking demand of the two parts of the parking lots are estimated respectively. 
Table 1 Results of the Parking Demand Forecasting Model.

a. Parking Demand Forecasting Model of the Northern Part

\begin{tabular}{|c|c|c|c|c|c|c|}
\hline & & & Estimate & SE & $\mathrm{t}$ & Sig. \\
\hline \multirow[t]{5}{*}{$\begin{array}{l}\text { Occupancy of parking } \\
\text { space }\end{array}$} & Constant & & 948.851 & $\begin{array}{r}27.91 \\
6\end{array}$ & 33.989 & $\begin{array}{r}.00 \\
0\end{array}$ \\
\hline & MA & Lag & -.926 & .035 & -26.74 & .00 \\
\hline & & 1 & & & 6 & 0 \\
\hline & & Lag & -.773 & .035 & -22.22 & .00 \\
\hline & & 2 & & & 3 & 0 \\
\hline Arrival passengers & Numerator & & .051 & .005 & 9.308 & .00 \\
\hline Arrival passengers (1 hour & Numerator & & .046 & .006 & 8.289 & .00 \\
\hline later) & & & & & & 0 \\
\hline Arrival passengers (2 hour & Numerator & & .032 & .006 & 5.664 & .00 \\
\hline later) & & & & & & 0 \\
\hline Departure passengers (1 & Numerator & & .017 & .005 & 3.426 & .00 \\
\hline hour later) & & & & & & 1 \\
\hline Departure passengers (2 & Numerator & & .020 & .005 & 4.108 & .00 \\
\hline hour later) & & & & & & 0 \\
\hline Departure passengers (3 & Numerator & & .022 & .005 & 4.446 & .00 \\
\hline hour later) & & & & & & 0 \\
\hline
\end{tabular}


b. Parking Demand Forecasting Model of the Southern Part

\begin{tabular}{|c|c|c|c|c|c|c|}
\hline & & & Estimate & $\mathrm{SE}$ & $\mathrm{t}$ & Sig. \\
\hline \multirow[t]{5}{*}{$\begin{array}{l}\text { Occupancy of parking } \\
\text { space }\end{array}$} & \multicolumn{2}{|l|}{ Constant } & $\begin{array}{r}1011.84 \\
5\end{array}$ & $\begin{array}{r}29.95 \\
8\end{array}$ & 33.776 & $\begin{array}{r}.00 \\
0\end{array}$ \\
\hline & \multirow{4}{*}{ MA } & Lag & -.840 & .037 & -22.64 & .00 \\
\hline & & 1 & & & 6 & 0 \\
\hline & & Lag & -.730 & .037 & -19.53 & .00 \\
\hline & & 2 & & & 5 & 0 \\
\hline Arrival passengers & \multicolumn{2}{|l|}{ Numerator } & .074 & .007 & 11.194 & .00 \\
\hline Arrival passengers ( 1 hour & \multicolumn{2}{|l|}{ Numerator } & .052 & .007 & 7.777 & .00 \\
\hline \multicolumn{3}{|l|}{ later) } & & & & 0 \\
\hline Arrival passengers (2 hour & \multicolumn{2}{|l|}{ Numerator } & .041 & .007 & 6.358 & .00 \\
\hline \multicolumn{3}{|l|}{ later) } & & & & 0 \\
\hline Departure passengers (2 & \multicolumn{2}{|l|}{ Numerator } & .025 & .006 & 4.360 & .00 \\
\hline \multicolumn{3}{|l|}{ hour later) } & & & & 0 \\
\hline Departure passengers (3 & \multicolumn{2}{|l|}{ Numerator } & .018 & .006 & 3.211 & .00 \\
\hline \multicolumn{3}{|l|}{ hour later) } & & & & 1 \\
\hline
\end{tabular}

The demand forecasting model of the northern part is

$X_{t}=948.851-0.926 X_{t-1}-0.773 X_{t-2}+0.051 A_{t}+0.046 A_{t+1}+0.032 A_{t+2}+0.017 D_{t+1}+0.020 D_{t+2}+0.022 D_{t+3}$

All the coefficients are significant and the R-squared is 0.88 . The obtained model well fits the data. 
According to Equation (2) and Table 1-a, the current occupancy of parking space is negatively related to the occupancy of the past two hours. Moreover, the current arrival passengers and the departure passengers in the coming $2 \sim 3$ hours influence obviously on the parking demand.

The demand forecasting model of the southern part is $X_{t}=1011.845-0.840 X_{t-1}-0.730 X_{t-2}+0.074 A_{t}+0.052 A_{t+1}+0.041 A_{t+2}+0.025 D_{t+2}+0.018 D_{t+3}$

All the coefficients are significant and the R-squared is 0.87 .

According to Equation (3) and Table 1-b, the current occupancy of parking space is also negatively related to the occupancy of the past two hours. However, compared with the model of the northern part, the departure passengers in the next hour does not have significant influence on the parking demand. It might result from more extra time set aside by the passengers from the south in case the unexpectedly bad traffic condition.

\section{References}

[1] Yan K., Parking demand forecasting model, Shenzhen International Conferences on City Static Transportation and Traffic Management. (1994) 25 28.

[2] Chen J., Wang W., Yan K., Forecasting research of urban parking facilities demand, Journal of Southeast University. 129 (1999) 121-126.

[3] Guan H., Wang X., Wang X., The research on forecasting method for parking demanding, Journal of Beijing University of Technology. 7 (2006) 600-604.

[4] Zhang J., A study of the planning method and its application for the urban parking, Urban Transport of China. 1(2003) 23-27.

[5] Bai Y., Xue K., Yang X., Forecasting method of parking-demand based on capacity-of-network, Journal of Traffic and Transport Engineering. 12(2004) 49-53. 
